\title{
8.7 Система методів і вправ для вивчення фразеологізмів у курсі української мови як іноземної
}

Фразеологізми належать до стійких мовних конструкцій, характерною особливістю яких є національна маркованість. Вони становлять країнознавчу цінність і відображають національну культуру носіїв мови-джерела. У зв'язку з цим під час вивчення стійких висловів в іноземній авдиторії виникають значні труднощі. Адже завдання викладача української мови як іноземної (УМІ) відпрацьовувати знання, уміння й комунікативні навички, які визначають здатність особи, для якої українська мова $є$ іноземною, застосовувати іiі для задоволення своїх суспільних, соціальних, побутових, освітніх, бізнесових, соціокультурних потреб. Нині для набуття громадянства України особа повинна підтвердити володіння українською мовою як іноземною на рівні В1. Це необхідний рубіжний рівень володіння УМІ, що уможливлює розгорнуте спілкування в повсякденних ситуаціях та в умовах комунікації з елементами непередбачуваности. Рубіжний рівень рекомендований для всіх іноземних громадян, щоб розпочати навчання в університетах України. Для здобуття ж ОКР «Бакалавр» необхідно володіти мовою на рівні В2 (середньому, достатньому), досягнення якого свідчить про можливість ефективного спілкування в українськомовному (і професійному) середовищі з усвідомленим використанням виражальних засобів та мовленнєвих умінь. 3 огляду на це вивчення українських фразеологізмів $\epsilon$ необхідним етапом в оволодінні мовою на достатньому рівні.

Дослідженням фразеологічних одиниць як аспектом вивчення лексики української мови в іноземній авдиторії займалися Т. Лагута, Ю. Сагата, М. Сціра, О. Тараненко, Н. Ядловська та ін. Фразеологію у формуванні мовної компетенції студентів у процесі викладання української мови як іноземної аналізували Ю. Жлуктенко, Г. Кузь, О. Кунін, Н. Скиба та ін. Фразеологічні еквіваленти й аналоги як засоби відтворення фразеологічних одиниць на позначення суб' єктів оцінки людини в українській та англійській мовах вивчали Р. Зорівчак, О. Кунін, Е. Солодуха та ін. Питання перекладу фразеологічних 
одиниць знайшли відображення в роботах А. Арсентєвої, Я. Баран, О. Білоуса, С. Флоріна, Ю. Шепеля та ін.

Незважаючи на те, що фразеологічні одиниці широко застосовуються в усному і писемному мовленні (художній літературі, публіцистиці та інших стилях мови), а особливості їхнього функціонування досліджено в різних наукових розвідках, аналіз методики вивчення цих стійких мовних конструкцій в іншомовній авдиторії потребує глибшого осмислення - з огляду на нові вимоги до рівнів володіння українською мовою як іноземною.

Мета дослідження - проаналізувати наявні й запропонувати оптимальні методи, які сприяють ефективному та поетапному вивченню фразеології на заняттях з української мови як іноземної; надати різні види завдань для вивчення, закріплення, повторення теми «Фразеологія», а також із метою перевірки знань і навичок студентів-іноземців.

Методисти вже запропонували декілька схем для системи опрацювання фразеологічних одиниць 3 іноземними студентами. Зокрема, Т. Лагута виокремила п’ять етапів вивчення української фразеології: 1) подання теоретичних відомостей про українську фразеологію; 2) пояснення нового фразеологічного матеріалу; 3) виконання різних видів вправ із метою закріплення вивченого; 4) повторення вивченого; 5) виконання певних видів роботи 3 метою перевірки знань і навичок іноземних студентів [628, с.с. 139]. Інші дослідники пропонують інтегрувати роботу з будь-яким текстом і в процес вивчення фразеологізмів [629, с.с.9]. Так, цей процес вони поділили на три етапи: 1) передтекстовий (передбачає мотивування студентів, підготовку до успішного виконання завдань, акцент на невідомій їм інформації, запитання, що сприяють формуванню навичок мовного прогнозування); 2) текстовий (пропонують низку завдань із метою розвитку комплексних комунікативних навичок, а також елементи однієї з форм контролю рецептивних навичок аудіювання); 3) післятекстовий (використання вихідного тексту як основи та опори для формування продуктивних умінь у різних видах мовлення; 
пропонують завдання, спрямовані насамперед на розвиток продуктивних умінь в усному мовленні, організовують мовленнєву діяльність студентів) [629, с.с. 9].

Правильне використання фразеологізмів сприяє поглибленню комунікативних умінь іноземних студентів, увиразнює їхнє мовлення, робить його живим, емоційним. Знання фразеології - це найвищий етап володіння студентами-іноземцями нерідною мовою, оскільки фразеологічні звороти - це одне із невичерпних джерел посилання експресивності та поглиблення логізації викладу [628, с.с. 137]. Тому вивчення фразеологізмів варто ретельно продумати й спланувати в такій, на наш погляд, оптимальній послідовності:

1. Надання теоретичних відомостей про українську фразеологію, фразеологічну одиницю, типи та джерела виникнення, ознайомлення студентів iз фразеологічними словниками, де подано значення цих стійких висловів, синонімійними чи антонімійними до них. Обсяг цих повідомлень має бути насиченим цікавими, доступними для сприйняття прикладами.

2. Пояснення нового фразеологічного матеріалу. Студенти-іноземці за допомогою викладача розтлумачують значення фразеологічних одиниць та вводять їх у контекст, який є матеріальним виразником ситуації, актуалізує значення фразеологізму. Опісля студенти повторюють уголос індивідуально або за викладачем наведений у контексті фразеологізм і записують його до спеціального фразеологічного словника, створеного ними. Це сприятиме кращому запам'ятовуванню.

3. Використання практичних завдань, різних видів вправ, узагальнювальних текстів із метою закріплення вивченого.

4. Використання проблемних завдань із системою перевірки знань і навичок іноземних студентів, а саме: проведення вибіркового фразеологічного диктанту, дискусій, рольових ігор, створення й розгадування кросвордів; складання діалогів та текстів. Така різноманітна робота поглиблює знання іноземних студентів, збагачує мовлення, розширює світогляд, виробляє навички українського мислення та уяви. 
На першому emani роботи 3 іноземними студентами викладач повинен зосередити увагу на фразеологізмах із дієсловами руху, зробити акцент на тому, що саме ці стійкі вислови уможливлять досягнення бажаного комунікативного рівня, оскільки за семантикою ці фразеологічні одиниці охоплюють аспекти найрізноманітнішої тематики. Рекомендуємо, наприклад, опрацювати такі фразеологізми: лізти у воду, не знаючи броду; налетіти, як мухи на мед; і вусом не повести; полетіти стрілою; залізти в петлю; нести тягар на своїх плечах; водити за ніс; тримати язик за зубами тощо.

Другим етапом роботи є пошук фразеологічних аналогів в інших мовах. Цей етап можна організувати за допомогою аналізу таких фразеологізмів: Попасти пальщем у небо - прийняти пухирі за ліхтарі (франц.); Ведмідь на вухо наступив - котяча музика (пол.); Теревені правити - австрійська розмова (пол.); Висіти на волоску - триматися на ниточці (англ.); Робити з мухи слона дивитися через збільшуване скло (ісп.); Червоний як рак - червоний як омар (англ.) тощо.

Пріоритетним способом перекладу фразеологічних одиниць $є$ переклад за допомогою фразеологічних еквівалентів. Це означає, що між співвідносними фразеологічними одиницями не повинно бути розходжень відносно змісту, метафоричності, емоційно-експресивного відмінку; еквіваленти повинні мати приблизно однаковий компонентний склад. Наприклад, рос.: взять быка за рога - узяти бика за роги (укр.) [630, с.с. 138].

На mpemьoмy emani варто розтлумачувати фразеологізми, які студентиіноземці зможуть використовувати в простих мовленнєвих конструкціях, наприклад: сидіти на телефоні, вийти сухим із води, біла ворона, водою не розлити, кров із молоком, крокодилячі сльози, пекти раків тощо.

На четвертому emani роботи можна використати фразеологічну синонімію та антонімію, зокрема запропонувати дібрати ці лексичні категорії-відповідники до вказаних одиниць: решетом у воді зірки ловити - байдики бити, ловити тави, ворон лічити; товкти воду у ступі - переливати з пустого в порожне, носити воду решетом; як n'яте колесо до возу - як собаці n'ята нога, як зайцеві бубон, 
як лисому гребінь (синоніми); жити чужим розумом - жити своїм розумом, мати свій розум; за тридев'ять земель - під носом, не за горами, рукою подати; купатися як сир у маслі - перебиватися з хліба на воду (антоніми).

Найбільш ефективним засобом для сприяння розумінню українських фразеологізмів в іноземній авдиторії є мотивування студентів до висловлювань 3 використанням фразеологічних одиниць. До того ж варто змоделювати в навчальному процесі умови спілкування, що наближені до реального життя. Сучасні інноваційні технології навчання надають можливість формувати навички усного мовлення іноземців із використанням українських фразеологізмів, зосередивши роботу на окремих навичках, які поступово об'єднуються в комплекс умінь. Це уможливить не тільки розуміння фразеологізмів у репліках співрозмовника, а й продукування висловів від свого імені $з$ доречним уживанням фразеологічних одиниць відповідно до ситуацій живої комунікації. Володіючи навичками спілкування 3 використанням фразеологізмів, студенти менш відчувають такі типові для говоріння чужою мовою проблеми, як недолік мовних і мовленнєвих засобів для розв'язання посталого завдання.

М. Сціра сформувала критерії добору фразеологічних одиниць для навчання студентів-іноземців на початковому рівні: 1) проста будова фразеологізму (слова в прямому значенні, 2 - 3 компоненти, проста морфемна структура); 2) прозора внутрішня форма (мотивація); 3) наявність країнознавчої інформації; 4) частотність уживання [631, с.с. 164].

Формування навичок усної комунікації із застосуванням фразеологічних одиниць передбачає передусім розвиток умінь діалогічного мовлення, тому на етапах закріплення та повторення вивченого матеріалу ефективною формою роботи є складання діалогу, що стимулює іноземних студентів до побудови зв’язного висловлювання, активізує вживання фразеологічних одиниць. Тут пропонуємо студентам-іноземцям завдання, які передбачають поступове збільшення самостійности студента в продукуванні власних висловлювань: відтворення діалогів-зразків із певними фразеологізмами, добір реплік у таких 
діалогах, конструювання діалогів із вказаними фразеологічними одиницями, інсценування складених діалогів тощо. Наприклад:

Завдання: прочитайте діалоги. Знайдіть фразеологізми, поясніть їхнє значення.

а) - Доброго дня, Мухамеде!

- Привіт, Омаре!

- Ти вже підготувався до сесії?

- Нi, я ще й за холодну воду не брався. А ти?

- А я вже не б'ю байдики, взявся за голову, як каже наша викладачка, $i$ прачюю з ранку до ночі. Тобі теж бажаю дати собі лад, бо сесія не за горами!

б) - Добридень, Амаду.

- Добридень, Макає.

- Як справи? Я телефоную тобі, а ти мовчиш, ніби в рота води набрав.

- Так, я вчора встав ні світ ні зоря, але, можливо, не на ту ногу, тому щьо бігав у справах увесь день як білка в колесі, потім до сьомих віників перекладав тексти, а ще довго ламав голову, у кого знайти конспект із математики; побіг світ за очі за ним, але не знайшов, врешті збився з ніг і не чую вже ні рук ні ніг, загалом, увесь день вертівся як бджола в окропі...

- Почекай, ти сиплеш словами як горохом і я нічого не розумію!

- Вчи фразеологізми - тоді ніколи не вскочиш у халепу, а будеш на коні!

в) - Привіт, Йомбу!

- Привіт, Луїсе!

- Ти вже склав іспит із фізики?

- Так, ие був мій зірковий час.

- Звичайно, ти нама ходяча енциклопедія! А я щуе не склав. Ти ж знаєш, щэо фізика - мій камінь спотикання. Мені ще треба пройти крізь вогонь, воду та мідні труби...

- Розумію, адже під лежачий камінь вода не тече, так?!

Складнішими є завдання відредагувати тексти поданих діалогів, змінивши в них соціальний або віковий статус учасників i, відповідно, змінивши 
використовувані етикетні формули. Замінити або додати також можна інші елементи, які мотивують вибір тієї або іншої мовленнєвої формули: мету, час, місце акту комунікації. Такі вправи будуть доцільними на просунутих рівнях вивчення мови - на етапі, коли студенти добре засвоїли базові конструкції українського мовного етикету [632, с.с. 178]. Студентам із високим рівнем мовленнєвих навичок можна запропонувати складання діалогів про життя студентів, використавши відомі їм фразеологізми.

Розвитку мовних та мовленнєвих навичок i вмінь, ефективно сприяє рольова гра - соціально-побутова або фахова, що передбачає наближене до реальности відтворення можливих життєвих ситуацій. Абсолютна перевага гри загалом та мовної зокрема в іiі здатності захоплювати, зацікавлювати, бути мотивувальним та розважальним чинником для учасників. Логічне мислення, здатність до пошуку відповідей на поставлені запитання, мовленнєвий етикет багато в чому покращуються саме внаслідок вивчення матеріалу за допомогою мовної гри. Крім того, завдяки ігровим моментам створюємо сприятливий психологічний клімат на заняттях, активізуємо мовленнєву діяльність іноземних студентів. Успішне проведення рольової гри можливе за умови поєднання методичних і психологічних чинників: 3 одного боку - відповідність рівню володіння мовою іноземних студентів, правильна організація гри, активізація необхідного лексико-граматичного матеріалу, з іншого - дружня атмосфера у групі, психологічна готовність студента взяти на себе роль і виконати їі (варто взяти до уваги психологічні особливості іноземних студентів різних країн та освітні традиції, до яких вони звикли [633, с.с. 20]), тактовність, коректність і творчі здібності викладача [634, с.с. 110].

Рольову гру можна проводити у двох варіантах:

- студенту пропонуємо роль іншої людини;

- студент зображує самого себе в певній ситуації.

Застосовуючи рольову гру, викладач повинен ретельно продумати, зі скількох етапів вона складатиметься, скільки часу триватиме і які утруднення, 
пов'язані з використанням запропонованих фразеологізмів, можуть виникнути в студентів. Фразеологічні одиниці, необхідні в пропонованій ситуації спілкування, доцільно написати на дошці й звернути на них увагу студентів до проведення гри. Потрібно також виділити час, щоб студенти обміркували свої дії та ролі. Можна дозволити зробити записи, необхідні для виконання ролі, але під час гри слід заохочувати імпровізацію, а не читання підготовленого тексту. Важливо, щоб студенти не боялися робити помилки, налаштувавшись на сприйняття помилки як невід’ємного елементу процесу навчання.

Під час вивчення української фразеології можна запропонувати такі ігрові ситуації і завдання:

1. Розмова в чаті. Після зустрічі з приятелями двоє друзів характеризують свого знайомого або знайому. Використайте фразеологізми, що позначають особливості характеру людини: золоте серцее,одні кістки та шкіра, як з гуски вода, як риба у воді, мухи не зобидить, грати першу скрипку, золоті руки, мокра курка, ні риба ні м'ясо, дитя природи, стріляний горобещьь, лихий на язик, майстер на всі руки, кров із молоком, ходячий довідник, аристократ духу, хоч свічки ліпи, $і$ за холодну воду не братися, палкий серияем, золота голова.

2. Проблемна ситуація. Студенти шукають ноутбук, що загубили. Використайте фразеологізми, які можна вживати в цій ситуації: як корова язиком злизала, вішати носа, збитися з ніг, ламати голову, за мить, битий час, багато води сплило, остання крапля, голова йде обертом, руки опустилися, бути на сьомому небі, думки колесом ходили, мов у воду впасти.

3. Гра «Заходьте в гості!» Використайте фразеологізми, які можна вживати в цій ситуації: добрий вечір,добридень вам, на добраніч, ваме здоров'я, добрий вечір вам у хату,усього найкращуого, здоровенькі були, спасибі за вашу милість, ласкаво просимо, слово честі, будьте так ласкаві, Бог на поміч.

4. Інтерв’ю на тему: «Правила життя справжнього студента», застосуйте фразеологізми, які можна вживати в цій ситуації: пройти вогонь $і$ мідні труби, вийти сухим із води, пройти крізь вогонь і воду, пускати в очі пилюку, плисти за 
течією, зупинити колесо історії, обіймати поглядом, сушити голову, хоч до рани прикладай, як мак прои̧вітає.

До найбільш продуктивних видів комунікативних заходів також належить дискусія, що має більш складну структуру й етапи підготовки та проведення. Дискусія дає змогу студентам обрати власну позицію, сприяє формуванню навичок відстоювати іï, тому для іiі проведення необхідно, щоб іноземні студенти, крім засвоєння певної кількости фразеологізмів, оволоділи вміннями формулювати, аргументувати, захищати свій погляд, дискутувати на цікаву для них тему. У процесі вивчення української фразеології студентам-іноземцям можна запропонувати такі теми для проведення дискусій:

1. Дерево сильне корінням, а людина - дружбою. Поясніть, що таке «дружба», використайте подані фразеологізми: вкласти душу, не розлий вода, жити чужим розумом, перебувати на короткій нозі, лікоть у лікоть, легкий на підйом, твердий горіх, золота душа, держати слово нерозлучний друг, друзі пізнаються в біді, світла голова, до кого пристанеш, такий і сам станеш.

2. Усе починається 3 любові. Висловіть свою позиціє 3 цього приводу, використавши подані фразеологізми: споріднена дуща, серце з перц̧ем, розуміти серцем, носити на руках, кам'яне серцее, одним миром мазані, знайти доріжку до серцุя, тернистий илях, розбити сериฺе, ходити одними стежками, небо прихилити, лицар серияя, втратити голову.

3. Два рази молодим не будеш. Для висловлення своєї думки використайте такі фразеологізми: золоте правило, народитися в сорочияі, жити своїм розумом, пан або пропав, майстер на усі руки, зірковий час, грати периу скрипку, місие під сонцем, легкий хліб, робота горить у руках, або все, або нічого, козел відпущеення, закопати талант у землю, камінь спотикання, сізіфова прачя,біла ворона.

4. Не соромно не знати - соромно не вчитися. Обгрунтуйте свою позицію за допомогою поданих фразеологізмів: вийти сухим із води, Альма-матер, джерело премудрости, ловити кожну хвилину, піти на свій хліб, працуювати до десятого 
поту, мати голову на плечах, золоті руки, брати бика за роги, знати, де раки зимують.

На завершальному етапі закріплення й систематизації вивченого пропонуємо творче завдання - скласти короткі розповіді, у яких доцільним було б уживання певних фразеологізмів. Це творче завдання не тільки дозволить викладачу визначити, наскільки засвоєно вивчений матеріал, але й виведе студентів на рівень самостійного висловлювання і створення мікротексту. А саме це і $є$ кінцевою метою навчання студентів-іноземців говоріння з використанням фразеологічних одиниць [635, с.с. 39] - формування здатності спілкуватися українською мовою в різноманітних ситуаціях, застосовуючи фразеологізми для пожвавлення процесу спілкування.

Отже, система методів та завдань для вивчення фразеологізмів у курсі УМІ передбачає ретельну підготовку кількома етапами, виважений підхід викладача на кожному рівні освоєння фразеологічних одиниць. Систематично організована робота з вивчення фразеологізмів в іншомовній авдиторії сприяє ефективному засвоєнню нових знань та практичному застосуванню їх у спілкуванні, адже вивчення фразеологізмів - один із найскладніших аспектів на заняттях з УМI. Водночас фразеологічні звороти є обов'язковою частиною лексичного i культурного мінімуму, який необхідний для адекватної комунікації іноземних студентів під час вивчення української мови як іноземної та для оволодіння мовою на середньому рівні В2. Без знання фразеологізмів іноземний студент не буде рівноправним учасником комунікації з носіями мови, яку він вивчає. Володіння фразеологічними одиницями сприяє відкритому діалогу культур, розширенню словникового запасу, формуванню лінгвокультурної компетенції іноземних студентів. 